\title{
Application of Ling Tien Kung Movement Technique in Reducing Diabetes Mellitus in Elderly
}

\author{
Nyna Puspita Ningrum, Retno Setyo Iswati, Indria Nuraini \\ University of PGRI Adi Buana, Indonesia \\ nyna@unipasby.ac.id
}

\begin{abstract}
Diabetes Mellitus (DM) in the elderly is a disease with blood glucose levels increasing from the normal value affected by the insulin hormone. As the age increases, the risk of DM increases, due to a decrease in physiology and biochemistry in the body's system. Therapy or solutions that can be done to overcome diabetes in the elderly can be done pharmacological or non-pharmacological. One of the non-pharmacological therapies is by doing the Ling Tien Kung movement. The Ling Ting Kung movement is a therapy centered on anal training, "empet-empet anus" and "tiptoeing". The general objective of this research was to determine the results of the Application of Ling Tien Kung Movement Technique in Reducing Diabetes Mellitus in the Elderly. This research method is quantitative analytical research with the approach of one group pretest post-test design. The population in this research were all participants of the Ling Tien Kung movement technique in Aryo Bebangah Sidoarjo club in the amount of 52 people, the sampling technique used was total sampling in accordance with the criteria of inclusion and exclusion, so that 48 people were obtained. Retrieval of data using observation before and after doing Ling Tien Kung movement therapy for two months.

The data were tested for validity using the product moment validity test method. To find out the validity of using the reference $\mathrm{r}$ table $=0.285$ (for $\mathrm{N}=48$ respondents). From the results of the validity test it is known that $\mathrm{r}$ count $=0.831$ (for $\mathrm{N}=48$ respondents), it can be concluded that the data is valid because $r$ count $>r$ table. The results obtained by the chi square reliability test value of $\mathrm{x}$ count $=6.154$ which is greater than the value of $\mathrm{x}$ table $=$ 3.841 (for $\mathrm{N}=48$ respondents). So it can be concluded that the Ling Tien Kung movement technique affects the decrease in blood sugar levels in the respondents.
\end{abstract}

Keywords: Ling Tien Kung Movement, Diabetes Mellitus

Received July, 25, 2019; Revised August 24, 2019; Accepted September 13, 2019 


\section{STRADA Jurnal Ilmiah Kesehatan}

DOI: $10.30994 /$ sjik.v8i2.191

ISSN: 2252-3847 (print); 2614-350X (online)

Vol.8 No.2. November 2019. Page.74-79

\section{BACKGROUND}

Diabetes mellitus (DM) in Indonesia is still in the fourth position as the country with the largest population suffering from diabetes after the United States, China, and India (WHO, 2011). In 2008 DM patients were estimated to reach 17 million DM patients from 220 million Indonesians. In a country, one of the main indicators of community health is increasing life expectancy (Tapan, 2015). Increased life expectancy means that more and more elderly people (elderly).

According to the Government Regulation of the Republic of Indonesia Number 43 of 2004, the elderly (elderly) is someone who has reached the age of 60 years and over (Kemenkes RI, 2017). With increasing age, the condition and function of the body decreases, it is not surprising that at an advanced age more and more complaints are conveyed because the body's system no longer works as well as when young (Salim.O.C, 2007). Decreasing body capacity in responding to stimuli in the elderly causes difficulty in maintaining body stability in the elderly. One system of the body that has decreased is a system of regulating blood glucose levels.

Disorders of regulation in blood glucose in the elderly who play the most role is insulin resistance. Insulin resistance often occurs in the elderly due to a decrease in physical activity resulting in a decrease in insulin receptors, changing patterns of food intake to more carbohydrates, and changes in neurohormonal. The habit of consuming sweet foods is also at risk twice as much as suffering from DM. Unconsciously stress also plays a role in triggering blood glucose levels, which results from an increase in the secretion of the glycogen hormone that causes glycogenesis and glyoneogenesis by the liver, on the other hand insulin resistance to break down glucose (Black, 2014).

From the description above, it is necessary to have an alternative therapy or solution that is easy to do to prevent and overcome the problem of diabetes mellitus in the elderly in nonpharmacological ways. One of them is the application of Ling Tien Kung movement technique in reducing diabetes in the elderly.

Ling Tien Kung is an energy therapy movement technique that activates natural healing energy (Swee, 2015). The healing process in energy therapy by returning energy that has become weak, disturbed or unbalanced (Eden, 2010).

\section{OBJECTIVE}

This study aimed to determine the results of the Application of Ling Tien Kung Movement Technique in Reducing Diabetes Mellitus in the Elderly.

\section{METHODS}

This research is a quantitative analytical research because the research method was carried out with the main objective of analyzing the effect of applying the ling tien kung movement technique to the reduction or decreasing of diabetes mellitus. Analysis is based on preexperimental design, which is a form of experimental research design that manipulates independent variables that influence the formation of dependent variables.

The independent variable in this research is the ling tien kung movement technique. The dependent variable in this study was the level of diabetes mellitus. The study was conducted at Ling Tien Kung gymnastic training center Aryo Bebangah club, with a population of all participants in the Ling Tien Kung movement training association at Aryo Bebangah Sidoarjo in July-August 2018 with 52 people. The research sample is total sampling 


\section{STRADA Jurnal Ilmiah Kesehatan}

DOI: $10.30994 /$ sjik.v8i2.191

ISSN: 2252-3847 (print); 2614-350X (online)

Vol.8 No.2. November 2019. Page.74-79

technique that has fulfilled the inclusion and exclusion criteria, so that a sample of 48 people is obtained.

The research data collection tools and methods were carried out by means of a group of subjects observed, blood sugar levels were examined to assess blood sugar levels before Ling Tien Kung exercises were carried out and after exercise intervention were observed again to determine the effectiveness of the ling tien kung movement techniques in reducing diabetes mellitus in the elderly.

In this research the data were tested for validity using the product moment validity test method to determine the validity of the application of the ling tien kung movement technique in reducing diabetes in the elderly. With reference $\mathrm{r}$ table $=0.285$ (for $\mathrm{N}=48$ respondents). After the data is collected, the data reliability analysis will be carried out as follows: Data in the form of variables to be examined, namely nominal and ordinal variables will be tested using Chi Square Test with a relationship level of 0.05 ( $\mathrm{x}$ value of table $=3.841$ ).

\section{RESULTS}

The results that have been achieved in the research conducted at the Aryo Bebangah club in July August 2018, the respondents who participated in this study were 52 people and those who fit the inclusion criteria were 48 people.

\begin{tabular}{cccc}
\hline Number & Age & $\mathrm{N}$ & $\%$ \\
\hline 1 & $60-65$ year & 25 & 52.08 \\
\hline 2 & $66-70$ year & 15 & 31.25 \\
\hline 3 & $>70$ year & 8 & 16.67 \\
\hline Total & & 48 & 100.00 \\
\hline
\end{tabular}

In the presentation of table above, shows that based on the age of the respondents, ages $60-65$ years were 25 respondents $(52.08 \%)$. Respondents aged 66 - 70 years were 15 respondents $(31.25 \%)$ and above 70 years old 8 respondents $(16.67 \%)$.

\begin{tabular}{cccc}
\hline Number & Gender & $\mathrm{N}$ & $\%$ \\
\hline 1 & Male & 17 & 35.42 \\
\hline 2 & Female & 31 & 64.58 \\
\hline Total & & 48 & 100.00 \\
\hline
\end{tabular}

In the presentation of table above, shows that based on respondents gender, male respondents were 17 respondents $(35.42 \%)$. Female respondents were 31 respondents $(64.58 \%)$.

Distribution of respondents based on blood sugar levels (Pre-test)

\begin{tabular}{cccc}
\hline Number & Blood Sugar Levels & $\mathrm{N}$ & $\%$ \\
\hline 1 & $\leq 140 \mathrm{mg} / \mathrm{dl}$ & 12 & 25.00 \\
\hline 2 & $140-200 \mathrm{mg} / \mathrm{dl}$ & 28 & 58.33 \\
\hline 3 & $\geq 200 \mathrm{mg} / \mathrm{dl}$ & 8 & 16.67 \\
\hline Total & & 48 & 100.00 \\
\hline
\end{tabular}

Respondents with blood sugar levels range $<140 \mathrm{mg} / \mathrm{dl}$ were 12 respondents $(25.00 \%)$, range 140

- $200 \mathrm{mg} / \mathrm{dl}$ were 28 respondents $(58.33 \%)$ and respondents with blood sugar levels range $>200$

$\mathrm{mg} / \mathrm{dl}$ were 8 respondents $(16.67 \%)$. 


\section{STRADA Jurnal Ilmiah Kesehatan}

DOI: $10.30994 /$ sjik.v8i2.191

ISSN: 2252-3847 (print); 2614-350X (online)

Vol.8 No.2. November 2019. Page.74-79

Distribution of respondents based on the implementation of the Ling Tien Kung movement

\begin{tabular}{cccc}
\hline No & Implementation of Ling Tien Kung movement & N & $\%$ \\
\hline 1 & Less appropriate & 9 & 18.75 \\
\hline 2 & Appropriate & 39 & 81.25 \\
\hline Total & & 48 & 100.00 \\
\hline
\end{tabular}

Based on the implementation of the Ling Tien Kung movement, the respondents were less appropriate were 9 respondents (18.75\%), and the corresponding were 39 respondents $(81.25 \%)$.

Distribution of respondents based on blood sugar levels (Post-test)

\begin{tabular}{cccc}
\hline No & Blood sugar levels & $\mathrm{N}$ & $\%$ \\
\hline 1 & $\leq 140 \mathrm{mg} / \mathrm{dl}$ & 32 & 66.67 \\
\hline 2 & $140-200 \mathrm{mg} / \mathrm{dl}$ & 12 & 25.00 \\
\hline 3 & $\geq 200 \mathrm{mg} / \mathrm{dl}$ & 4 & 8.33 \\
\hline Total & & 48 & 100.00 \\
\hline
\end{tabular}

Respondents with blood sugar levels range $<140 \mathrm{mg} / \mathrm{dl}$ were 32 respondents (66.67\%), range 140 $-200 \mathrm{mg} / \mathrm{dl}$ were 12 respondents $(25.00 \%)$ and respondents with blood sugar levels range $>200$ $\mathrm{mg} / \mathrm{dl}$ were 4 respondents $(8.34 \%)$.

Table 7 - Cross Tabulation "Application of ling tien kung movement techniques in reducing diabetes in the elderly"

\begin{tabular}{cccccccc}
\hline \multirow{2}{*}{$\begin{array}{c}\text { Number } \\
\end{array}$} & $\begin{array}{c}\text { Blood sugar levels } \\
\text { Implementation }\end{array}$ & Decrease & $\%$ & Constant & $\%$ & Total & $(\%)$ \\
\hline 1 & Appropriate & 35 & 72.92 & 4 & 8.33 & 39 & 81.25 \\
\hline 2 & Less appropriate & 5 & 10.42 & 4 & 8.33 & 9 & 18.75 \\
\hline & Total & 40 & 83.34 & 8 & 16.66 & 48 & 100.00 \\
\hline
\end{tabular}

Based on the table above, which shows that of the 48 respondents in this research respondents whose blood sugar levels decrease were 35 respondents (72.92\%) by carrying out appropriate movements accordingly, 5 respondents $(10.42 \%)$ by carrying out the ling tien kung movement in a less corresponding. While respondents whose blood sugar levels remained were 4 respondents $(8.33 \%)$ by carrying out appropriate movements accordingly and 4 respondents $(8.33 \%)$ by carrying out ling tien kung movements in a less appropriate manner.

\section{DISCUSSION}

In the research of the application of Ling Tien Kung's movement techniques in reducing diabetes mellitus in the elderly at Aryo Bebangah club, which was attended by 48 respondents with mostly female participants, namely 31 people $(64.58 \%)$ and mostly aged $60-65$ years were 25 respondents $(52.08 \%)$. Cross tabulation result of the application of ling tien kung movement technique in reducing diabetes in the elderly found that most of the respondents who carried out the ling tien kung movement accordingly or correctly their blood sugar levels dropped by as many as 35 people $(72.92 \%)$.

Along with increasing age, more and more elderly people are at risk of developing Diabetes Mellitus (DM). DM is characterized by the inability of the body to metabolize carbohydrates, fats, and proteins which leads to conditions of hyperglycemia (Black and hawks, 2014). Several factors that support the emergence of DM are genetic, age, sex, food 


\section{STRADA Jurnal Ilmiah Kesehatan}

DOI: $10.30994 /$ sjik.v8i2.191

intake, obesity, physical activity, and stress. Physical exercise is very helpful in people with DM, because exercise can improve body fitness, improve heart and lung function. One of the alternative physical exercises that is suitable for the elderly is a movement that does not require much energy, one of which is Ling Tien Kung practice. Ling Tien Kung is a study of the existence of an energy in the human body that determines "life energy" and learns the techniques of movement to influence it. Ling Tien Kung is not gymnastics, not aerobics and not sports or Taichi Chuen, but is a movement healing technique for diseases. Ling Tien Kung is centered on anal training (rectal gymnastics) or "empet-empet anus".

Ling Tien Kung's movement technique has many variations of stretching movements that can help expedite the metabolism and blood flow in the body so that the circulation of oxygen, nutrients, and metabolic results in the body will be more smooth (Swee, 2015). The healing process in energy therapy by returning energy that has become weak, disturbed or unbalanced (Eden, 2010). The ling tien kung exercise movement by performing breathing that is identical to the yoga movement can help regulate the work of the adrenal pituitary hypotalamus and the central nervous system which can arise due to the presence of stressors so that it reduces cortisol and affects blood sugar levels.

Foot-centered exercise, which is doing tiptoeing (Lik Thie Tien Tien). This movement can improve blood circulation, when the heel is lifted the muscles contract, the largest blood vessels filled with blood reduce the buildup of blood sugar in the legs and stimulate the leg nerves not to numb (Swee, 2015). When the heel drops, the blood turns and immediately begins to move towards the heart so that it can reduce tension. When doing stretching exercises on ling tien kung exercises, muscles need glucose as a source of energy, so that metabolic needs will increase and will have an impact on increasing muscle glucose uptake, resulting in a decrease in blood sugar levels.

The results of this research were strengthened by the chi square reliability test value of $\mathrm{x}$ count $=6.154$ which is greater than the value of $\mathrm{x}$ table $=3.841$ (for $\mathrm{N}=48$ respondents). So it can be concluded that the Ling Tien Kung movement technique affects the decrease in blood sugar levels in the respondents.

The results of the above research are supported by research conducted by Ardiansyah (2012) by passing Ling Tien Kung movements as much as 2 times a week, with the duration of implementation of approximately 30 minutes for 3 weeks can reduce blood sugar levels in DM patients. The many variations of Ling Tien Kung's motion are useful to facilitate blood flow and body metabolism, so that the flow of oxygen, nutrients and metabolic waste becomes smooth (Muhammad et al, 2014)

\section{CONCLUSION}

The application of the Ling Tien Kung Movement Technique in reducing diabetes mellitus in the majority of the elderly has decreased by 35 respondents $(72.92 \%)$. On the value of the chi square reliability test obtained $\mathrm{x}$ count $=6.154$ which is greater than the value of $\mathrm{x}$ table $=3.841$ (for $\mathrm{N}=48$ respondents). So it can be concluded that the Ling Tien Kung movement technique affects the decrease in blood sugar levels in the respondents 


\section{STRADA Jurnal Ilmiah Kesehatan}

DOI: $10.30994 /$ sjik.v8i2.191

ISSN: 2252-3847 (print); 2614-350X (online)

Vol.8 No.2. November 2019. Page.74-79

\section{REFERENCES}

Ardiansyah, M., \& Fatkhur, R. M. Q. (2012). Relationship between hyperglycemia, old age and suffering from diabetes patients with neuropathy events numbers diabetika. FKKIK (Doctor Of Education). Vol. 8, no. 9.

Black, J., \& Hawks, j. (2014). Medical Surgical Nursing: Clinical Management to the expected results. Townhouse translated it by Nampira r. Emban Salemba Jakarta: Patria.

Eden, d. (2010). DONNA EDEN'S ENERGY MEDICINE 101 CLASS HANDOUTS. Retrieved September 21, 2014, from innersource.

Kemenkes RI. (2017). Data Center and information. Jakarta.

Nursalam. (2013). The concept of application of Research methods of Nursing. Salemba Jakarta Medika.

Salim, OC, Sudharma, n. i. Kusumaratna, r. k., \& Hidayat, a. (2007). Validity and reabilitas World Health Organization Quality of Life-BREF quality of life for the elderly. Universa Medicina.

Swee, A. (2015). Ling Tien Kung, Making People Healty. Edition II. Surabaya: Insan Cendekia.

Tapan. (2015). degenerative diseases. Jakarta: Elex Medika Komputindo.

WHO. (2011). Prevention of Diabetes Melllitus. Technical Report Series, Geneva. 